\title{
Finland, civil war and revolution, 1914-1918
}

\author{
Kyle E. Frackman
}

The revolution or civil war of 1917-18 in Finland is one of the decisive events in the nation's history. Representing a forceful break with Russia, which had controlled Finland since 1809, the conflict put Finland on the short path toward independence and democratization. The concerted movement for independence began around World War I, as the Finnish political scene had previously been absent of plans for separation from Russia. The only revolutionary tendency before World War I was for a restoration of Finnish autonomy within the Russian empire.

Since the thirteenth century, Finland had been under Swedish rule, administered by Swedishspeaking nobles and bureaucrats. For some 
time and to varying degrees, many Finns had been dissatisfied with their position under Sweden's control. Finland found itself situated literally between these two greater powers. Nonetheless, Sweden-Finland had the benefit of a strong constitutional government, something that Russia began using to its advantage already in the eighteenth century in order to weaken the position of the Swedish monarch. In 1809, following the successful military efforts of Alexander I of Russia (1777-1825), Finland became a part of the Russian empire. As part of the Grand Duchy of Finland, Finns were promised autonomy under the Russian tsars.

From Finland's creation as a Grand Duchy through the 1880s, Finnish autonomy was largely a reality. As it had before, Russia encouraged the constitutional aspirations of Finns, because it furthered the separation of Finland from its former ruler, Sweden. Alexander III (1845-94), however, who ascended the throne in 1881, grew increasingly critical of Finland's exceptional status as an autonomous Grand Duchy. He was not alone, as concerns about Finnish connections to Germany, Sweden, and Britain abounded and agitated Russian nationalists. In 1890, Alexander III initiated a series of efforts aimed at bringing Finland under tighter Russian control. After Alexander's death and the accession of Nicholas II (1868-1918), this period of Russification continued and expanded throughout the Russian empire. In Finland, this gained full force in 1899 when Finnish legislation came under the purview of the Russian government, starting the first "period (or years) of oppression" (sortokausi or sortovuodet in Finnish).

There were several factors that contributed to the revolutionary climate in Finland in the first quarter of the twentieth century. First and foremost were conflicts and friction between Finland and Russia. The aforementioned Russification fomented conflict as it prevented or hindered Finnish control of national legislation. Finns desired representation in the Russian parliament, the Duma, created after the tsar's 1905 allowance. Largely involuntary support of the Russian military was required and simultaneously offensive to a great portion of the Finnish population. Russian involvement in official uses of Swedish and Finnish fostered Finnish national antagonism. Additionally, there was internal Russian discord over Finland's exceptional status as a Grand Duchy. Furthermore, Finns were increasingly indignant about the poor state of the Finnish economy and the country's overwhelming poverty. These sources of Finnish rancor led merely to developing support of the restoration of Finnish autonomy; up to 1910 none of the political parties was planning on Finland becoming an independent nation.

Two groups were integral in the developments surrounding Finland's conflicts with Russia. The Young Finnish Party (Nuorsuomalainen Puolue) or Young Finns (nuorsuomalaiset) became a political party in the 1890 s, comprising a younger generation of Finnish speakers as well as Swedish-speaking liberals who sought a constitutional solution to problems with Russia. Many Finnish nationalists were suspicious of the Young Finns, because of their willingness to collaborate with the Swedish-speaking upper class. The Old Finns (vanhasuomalaiset) or the members of the Finnish Party (Suomalainen Puolue), on the other hand, were concerned that the Young Finns' desired resistance would further erode the Grand Duchy's autonomy and wished to cooperate as much as possible with the Russian government. Internal Russian strife, specifically the 1905 Revolution, made it possible for the Finnish Diet (Suomen valtiopäivät) to abolish the system of the four Estates with the creation of a new unicameral, 200-member legislative body, the Eduskunta. Suddenly, Finland had a progressive form of government elected by equal and universal suffrage. Despite these advances, Finnish civil rights continued to be threatened until Finland had complete independence.

Again in 1917 internal Russian affairs created a climate in which Finland's status could change. Following the "March Revolution" in which the tsar was overthrown, political dissidents who had been living in exile returned to Finland after the replacement of the Russian GovernorGeneral Franz Albert von Seyn (1862-1918) by Mikhail Stakhovich (1861-1923). The new provisional government reinstated Finland's constitutional rights. Simultaneously, parliament convened after a 1916 election in which the Social Democratic Party (Suomen Sosialidemokraattinen Puolue) was overwhelmingly victorious and elected a government headed by Oskari Tokoi (1873-1963), who was the first socialist in the world to become prime minister of a 
democratically elected government. On July 18, 1917, the Eduskunta passed an Enabling Act or Power Act in order to proclaim Finland's independence from Russia in all areas except defense and foreign affairs. The Russian provisional government, however, did not accept and promptly dissolved the parliament in favor of new elections, in which the conservatives then took power. Leaders of the Democratic Party and the Trade Union Federation called a general strike for November 14, 1917. According to Oskari Tokoi, "what ensued was more than a strike; it was rebellion and revolution" (Singleton 1998: 107). A new government, elected by the Eduskunta, assumed control under the leadership of a conservative Finnish nationalist, Pehr Evind Svinhufvud (1861-1944). This new parliament issued on December 6, 1917 a declaration of independence drafted by K. J. Ståhlberg (18651952), which Vladimir Ilyich Lenin (1870-1924) promptly accepted.

Meanwhile, tension grew between two active segments of the population, namely the Reds (punaiset), the socialists, and the Whites (valkoiset), the non-socialist conservatives. The Finns had no army, due to the waiving of conscription for soldiers in favor of a monetary contribution to Russian military efforts. In the disorder during and following the Russian revolutions of 1917, the absence of force was filled by the Red Guards, formed by the labor movement, and the White Guards, organized and populated by conservatives and nationalist youth, volunteers from Finland and Sweden, and defectors from the Russian army. Some of the Whites had been secretly trained in the Prussian 27th Jäger Battalion, specially created to support the cause of Finnish independence from Russian and Germany's interests therein.

On January 27/28, 1918, civil war finally erupted. Overnight, the Red Guards took control of Helsinki and declared a revolutionary government, the People's Commission (Kansanvaltuuskunta), headed by Kullervo Manner (1880-1939). With the Whites headquartered in Vaasa under the command of Carl Gustaf Emil Mannerheim (1867-1951), an Imperial army general, Finland was effectively divided between the Whites' area of control in the north and the Reds' area, including the cities of Pori, Tampere, Lahti, Lappeenranta, and Viipuri in the south. In addition to the Finnish Jäger battalion, more German forces arrived in February to aid the Whites' efforts to take back Tampere and Helsinki. The latter fell on April 13, 1918 to a German expeditionary force led by General Rüdiger von der Goltz (1865-1946). The end of the civil war was celebrated with a parade in Helsinki on May 16, 1918. It has been estimated that around 5,500 men on both sides died in battles, although this figure does not include numbers of executions and deaths by neglect or starvation in prison camps. Indeed, another source approximates the casualties of the revolution to be 23,000 people, that is, those killed legally and illegally as a result of battle and acts of "terrorism."

As the violence ceased, the pressing issue facing Finns was how their government would be structured. The two options under consideration were monarchy and republic. Not unrelated to Germany's considerable involvement and support in the revolution, a German, Prince Friedrich Karl of Hesse (1868-1940), was offered the crown. The issue became irrelevant after Germany's defeat in World War I. Svinhufvud, who had been regent of Finland, stepped down and was succeeded by Mannerheim. Following new elections and a new constitution, Mannerheim lost as the rightwing candidate to Ståhlberg, a leading force behind the constitutional reform, who became the first president of the Republic of Finland.

SEE ALSO: Anarchism, Finland; International Socialism: Mass Politics; Lenin, Vladimir Ilyich (1870 1924); Russia, Revolution of 1905-1907; Russia, Revolution of February/March 1917; Russia, Revolution of October/November 1917; Socialism

References and Suggested Readings

Alapuro, R. (1988) State and Revolution in Finland. Berkeley: University of California Press.

Envall, M. (1998) The Period of Independence I, 1917-1960. In G. Schoolfield (Ed.), A History of Finland's Literature. Lincoln: University of Nebraska Press.

Kirby, D. (2006) A Concise History of Finland. Cambridge: Cambridge University Press.

Laitinen, K. (1998) The Rise of Finnish-Language Literature. In G. Schoolfield (Ed.), A History of Finland's Literature. Lincoln: University of Nebraska Press.

Schoolfield, G. (1998) A Sense of Minority. In G. Schoolfield (Ed.), A History of Finland's Literature. Lincoln: University of Nebraska Press.

Singleton, F. (1998) A Short History of Finland. Cambridge: Cambridge University Press.

Upton, A. (1980) The Finnish Revolution 1917-1918.

Minneapolis: University of Minnesota Press. 